\title{
THE EFFECTIVENESS TEST OF BETEL LEAF EXTRACT TOWARD THE DEVELOPMENT OF AEDES AEGYPTI SP LARVAE
}

\author{
Uji Efektivitas Ekstrak Daun (Piper Befle L.) Sirih Terhadap Perkembangan Larva \\ Aedes Aegypti Sp
}

FIRZA KHAIRULLAH S, RIYANI SUSAN BT HASAN

Medical Education Study Program, Medical Faculty, Universitas Prima Indonesia Email: firza2204@gmail.com

\begin{abstract}
This research was conducted to determine the effectiveness of betel leaf extract conducted at a concentration of $2.5 \%, 5.0 \%, 7.5 \%, 10 \%$ as larvicide toward the development of Aedes Aegypti Sp. Aedes Aegypti Sp larvae are dangerous vectors in Dengue Hemorrhagic Fever (DHF) in humans. The method in this research was carried out on an experimental method by using a post-test only design and sampling with a purposive sampling method. The effectiveness of betel leaf extract larvicide on the development of Aedes Aegypti Sp larvae was carried out by mixing betel leaf extract with several concentrations in one container Aedes Aegypti Sp larvae inside. The results obtained in this research were carried out by the Kruskal-Wallis test, the test found that there was a significant difference because it was given a $95 \%$ confidence index. The larvae treated with betel leaf extract with a concentration of $10 \%$ had the highest effectiveness in stopping the development of Aedes Aegypti Sp larvae, which proved at the mortality at a concentration of $10 \%$, found total mortality of 20 larvae in 8 hours of treatment. Betel leaf extract with a concentration of $10 \%$ had the highest effectiveness of discontinuing the development of Aedes Aegypti Sp larvae.
\end{abstract}

Keywords: Betel Leaf Extract and Aedes Aegypti $S p$

\begin{abstract}
Abstrak Penelitian ini dilakukan agar mendapatkan keefektivitasan ekstrak daun sirih yang dilakukan di konsentrasi 2,5\%, 5,0\%, 7,5\%, 10\% sebagai larvasida terhadap perkembangan larva Aedes Aegypti Sp. Larva Aedes Aegypti Sp merupakan vektor yang berbahaya pada penyakit Demam Berdarah Dengue (DBD) pada manusia. Metode pada penelitian ini dilakukan pada metode eksperimental dengan desain post-test only design dan pengambilan sample dengan metode Purposive sampling. Uji efektivitas larvasida ekstrak daun sirih terhadap perkembangan larva Aedes Aegypti Sp dilakukan dengan cara dicampurkan esktrak daun sirih dengan beberapa konsentrasi pada satu wadah yang sudah diletakkan larva Aedes Aegypti Sp. Hasil yang didapat pada penelitian ini yang dilakukan dengan uji Kruskal-Wallis, uji tersebut dijumpai bahwa terdapat perbedaan yang signifikan karena diberikan indeks kepercayaan 95\%. Pada larva yang diberikan perlakuan ekstrak daun sirih dengan konsentrasi $10 \%$ memiliki efektivitas tertinggi dalam menghentikan perkembangan larva Aedes Aegypti Sp, yang terbukti kematian pada konsentrasi $10 \%$ didapati total kematian 20 larva pada 8 jam perlakuan. Ekstrak daun sirih dengan konsentrasi $10 \%$ memiliki efektivitas tertinggi dalam menghentikan perkembangan larva Aedes Aegypti Sp.
\end{abstract}

Kata Kunci : Ekstrak Daun Sirih dan Aedes Aegypti 


\section{INTRODUCTION}

The vision of the Ministry of Health Republic of Indonesia in 2014-2019 is Indonesian people to be independent, fair and healthy. One of the criteria of a community which can be considered as independent in the health field is that the community's soul can fix the existing personal health condition of the community by recognizing the possibilities which will occur in that community (Adibah \& Dharmana, 2017).

Indonesia can be dubbed as a maritime and tropical forest country because based on the natural facts in Indonesia, the biodiversity in Indonesia is around 25,000 species consisting of flowers and plants. This amount exceeds the other tropical rich countries in the world which is West Africa, and among the diversity of flowering plant species, most of them can be used as medicinal plants (Zuhud, Tumbuhan, Kehutanan, \& Pertanian Bogor, n.d.).

Traditional medicine in Indonesia is currently used as herbal medicines as well as food which can be useful for maintaining endurance, and the food and beverage industry (Medicinal, 2015). One of the medicinal plants in Indonesia contains more than one active ingredient that is very useful as herbal medicine is from the Piperaceae family which is betel plant or betel leaf (Piper Betle L.)

To Recognize betel leaf is not too difficult because this leaf is found in various areas and this plant grows by propagating. In addition, because the leaf has special colors and the shape of the leaf that is not complicated to recognize. Indonesian people also use this betel leaf in the culture of 'nginang' or eating betel, and people also use it for sanitation and treatment. Furthermore, this leaf is widely used in the community for circumcisions and magical uses (Physiaological, 2014).

The betel plant (Piper Betle L.) can reach 15 meters high with the root of this plant is round and brown taproot. The betel leaf is a single leaf shaped like a heart, also a shiny surface leaf, the leaf is pointed and dark green. The betel leaf itself has about 6-17.5 cm length and 3.5-10 cm width (Sarjani, Pandia, \& Wulandari, 2017).

The betel leaf (Piper Betle L.) also has a pleasant aroma (Aromatic) and besides growing by propagating, this plant also grows alternately (Purnama, 2017).

The green betel leaf (Piper Betle L.) which commonly found in several areas and can usually be used as traditional medicine and antiseptic. This leaf is also a leaf that contains botanical larvaside active substances. Larvaside active substances in betel leaf are Saponins, Alkaloids, Essential Oils, Flavonoids, Tannins, and Polyphenols which are deadly against Aedes Aegypti mosquito larvae. Based on this consideration, some experts have used an alternative method of chemical control using natural insecticides which are insecticides which have a highly toxic effect on insects and have no harmful side effects on humans (Betriyon \& Yahya, 2013).

Besides traditional medicine and antiseptic, betel leaf is also used to treat other diseases. The betel plant also has benefits as an anti-ulcer, anti-allergic, anti-larvicide and antioxidant as well as anti-diabetic effects (Astriani \& Widawati, 2017)

Ardiyansyah stated that a good betel leaf was a fresh leaf which had no smell and had a dark green color, free from damage and does not contain pests. In betel leaf which contains a lot of sunlight shows the dark green leaf because the photosynthesis contained in plants and selected betel leaves can get more secondary metabolic than this leaf (Nyamuk, Wahdaningsih, Armyanti, Belakang, \& Berdarah, 2016)

In some regions in Indonesia and several countries other than Indonesia, it has a unique name or another name for the betel leaf, as follow:

a. Name in regions of Indonesia: ranub/sireh (Sumatra), sedah (Java), base (Nusa Tenggara), Uwit (Kalimantan), mota (Maluku), afo (Papua).

b. Name in other countries: tanul/tanbul (Arab), ju jiang (China), betel peper (England), betelpfefer (German), pan (India), eleballi (Canada), bakik serasa (Malaysia) (Astriani \& Widawati, 2017).

The biggest health problem in Indonesia is currently Dengue Hemorrhagic Fever (DHF). In Indonesia, dengue was first encountered in Surabaya city in 1968. The number of patients affected by DHF in 2014 was known with a total of 100,347 cases and a death rate recorded at around 907 people (Astriani \& Widawati, 2017). Female Aedes Aegypti mosquito is a vector which often infects. Aedes Albopictus mosquitoes can transmit the infection.

The Aedes Aegypti mosquito is the biggest vector causing DHF infection, and this Aedes Aegypti is an anthropophilic species and has an 
environmental compatibility. Besides, it can also breed in pools of water (Atsriani et al., 2016). 4 serotypes in dengue virus, namely DEN-1, DEN-2, DEN-3, DEN-4 currently do not have an effective vaccine that can provide protection.

The basic color of the Aedes Aegypti Sp mosquito which has a small size and has grown up has a black color. Black scales, short palpies and silver white tips on proboses. Scales are wide, have a white color and are on the elongated part found on Oksiput. White scales extending posteriorly and in the middle are found in the Femur. The tibia part of this mosquito also has a black color throughout. In the first to fourth basal segments contained in a circular position is part of the rear Tarsi. Scales that have a black color and measuring 2.5-3.0 $\mathrm{mm}$ are found on the wing (Soedarmo, 2008).

Therefore, the leading cause of DBD is a vector of Aedes Aegypti mosquito, the authors will conduct a study of the efficacy of betel leaf (Piper Betle L.) as larvaside extracted with ethanol as a solvent for the development of Aedes Aegypti larvae

\section{RESEARCH METHOD}

This research was conducted with an experimental method with a post-test design. This research used a design in the form of interventions which were carried out first then monitoring or post-test of the results. Treats were as independent variables and results as dependent variables.

The process of making betel leaf extract (Piper Betle L.) was carried out at the Faculty of Mathematics and Natural Sciences in the Laboratory of Chemistry and the anti-larvacide test of Aedes Aegypti Sp in September 2019 was carried out at the Faculty of Medicine at Prima Indonesia University in the Microbiology Laboratory.

In this research, the sample used was betel leaf (Piper Betle L.) obtained at the traditional market in Pancur Batu, Medan. And, the Aedes Aegypti Sp mosquito eggs were purchased at the Bandung Institute of Technology in the Biological Technology section.

The data collection method was conducted by sampling. This study uses extracts taken from betel leaf (Piper Betle L.) which have been dried and then added $96 \%$ ethanol solvent.

This research used tools such as measuring cup, Beaker glass, Maserator, Waterbath, Rotary evaporator, Dropper Pipes, Stirring
Rods, Filter Paper, Extraction Bottles, Scales, Mosquito larvae containers, and Mosquito nets.

This research uses betel leaf, Aedes Aegypti Sp mosquito larvae and $96 \%$ ethanol solution and aquadest as the material of this research.

The instrument used in this research had to be sterilized first by being washed thoroughly, then the instrument is placed in an autoclave at $121^{\circ} \mathrm{C}$, a pressure of $1.5 \mathrm{~atm}$ and sterilization was carried out within 15 minutes.

The betel leaf which had been purchased, finely sliced, so that the leaf became small, then the leaf was dried using an oven at $70^{\circ} \mathrm{C}$ until the leaf wilt and dry. The leaf was blended until smooth until the leaf become powdery form. Furthermore, the leaf powder is put into an extraction bottle, ethanol $96 \%$ as much as 20 liters is added, maceration was carried out for 3 days, and filtered using filter paper, and the filter has been placed into a rotary evaporator for evaporation, then carried out in a water bath until the extract becomes thick, and repeated with the same steps.

\section{Making Betel Leaf Extract}

Betel leaf extract was made in some various concentrations which were $2.5 \%, 5.0 \%, 7.5 \%$, $10 \%$ with the aquadest solution used as a thinner. Besides, the result of dilution was put into each vial bottle labeled according to its concentration made in $100 \mathrm{ml}$ of solvent:

a. The betel leaf of a concentration of $2.5 \%$. $25 \%$ concentration of betel leaf was taken $10 \mathrm{ml}$ then mixed into a container containing $100 \mathrm{ml}$ of water.

b. The betel leaf of a concentration of $5 \%$. $50 \%$ concentration of betel leaf was taken $10 \mathrm{ml}$ then mixed into a container containing $100 \mathrm{ml}$ of water.

c. The betel leaf of a concentration of $7.5 \%$. $75 \%$ concentration of betel leaf was taken $10 \mathrm{ml}$ then mixed into a container containing $100 \mathrm{ml}$ of water.

d. The betel leaf of a concentration of $10 \%$ $100 \%$ concentration of betel leaf was taken $10 \mathrm{ml}$ then mixed into a container containing $100 \mathrm{ml}$ of water.

\section{Dropping Aedes Aegypti Sp.}

Mosquito eggs dropping mosquito eggs was conducted in order to obtain larvae of Aedes Aegypti Sp, which were needed as samples in this research. The mosquito eggs were tested by: 
a. Mosquito eggs that had been prepared on filter paper sheets, were chosen as needed.

b. Place the selected mosquito eggs as needed to a container which has been given water before.

c. Prepare fish feed and blender a little.

d. Mix the fish feed that has been blended slightly, to a container of mosquito eggs.

e. Wait for 2 to 3 days, the eggs will drip.

\section{DATA ANALYSIS}

The result of Larvicidal activity test data which were obtained then processed using statistical software, which was SPSS using the KruskalWallis Test.

$\mathrm{H} 0$ : There is no discontinuing the development by the betel leaf extract toward Aedes Aegypti Sp larvae

H1: There is a cessation of development by the betel leaf extract toward Aedes Aegypti Sp larvae.

\section{RESULT AND DISCUSSION \\ Result}

Collecting the data conducted in this research was carried out on September, 12 $2^{\text {th }}-20^{\text {th }} 2019$ in the medical school of Universitas Prima Indonesia in the Laboratory of Microbiologists using a sample of the betel leaf extract (Piper Betle L.) which was tested on Aedes Aegypti Sp larvae.

Based on data collected and analyzed, the antilarvaside power obtained from the betel leaf extracts (Piper Betle L.) on the development of Aedes Aegypti Sp larvae tested by means of larvae mixed in a container containing the betel leaf extract at a concentration of $2.5 \%, 5.0 \%$, $7.5 \%, 10 \%$. And we obtained a termination/ discontinuation to the development of Aedes Aegypti Sp larvae in the figure and table below:

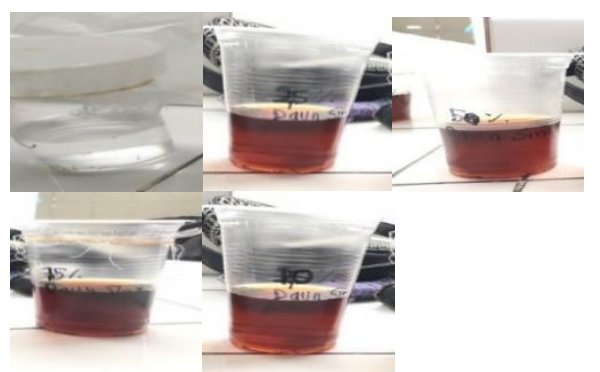

Figure 1. death of Aedes Aegypti Sp larvae in containers containing the betel leaf extract (Piper Betle L) with some concentration and negative control with containers containing Aquadest 96

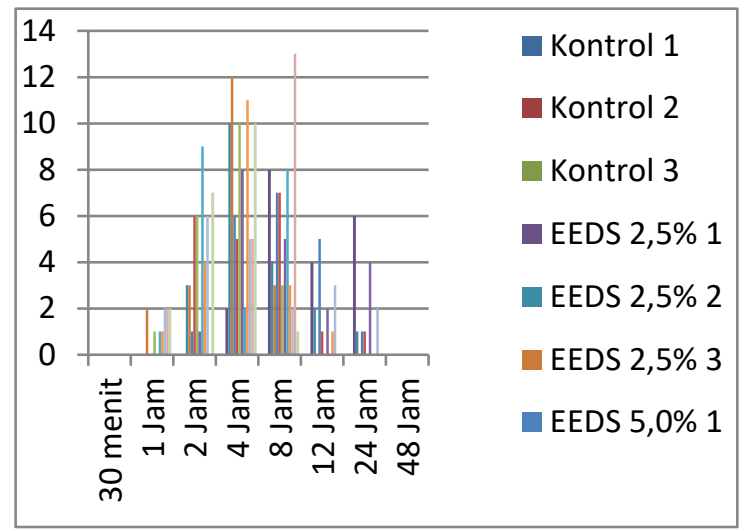

Figure 2. Death total of Aedes Aegypti larvae at 48 hours with repetition

Table 1. The percentage Results of total larvae that die in 3 replications up to 48 hours in a concentrations of $2.5 \%$ and $5 \%$

\begin{tabular}{lllllll}
\hline & \multicolumn{7}{c}{ Betel Leaf Extract } \\
$\begin{array}{l}\text { Repetition } \\
\text { concentration }\end{array}$ & I & II & III & I & II & III \\
\hline 30 minutes & 0 & 0 & 0 & 0 & 0 & 0 \\
1 hour & 0 & 0 & 10 & 0 & 0 & 5 \\
2 hours & 0 & 15 & 25 & 5 & 30 & 35 \\
4 hours & 10 & 65 & 85 & 35 & 55 & 85 \\
8 hours & 50 & 85 & 100 & 70 & 90 & 100 \\
12 hours & 70 & 95 & 100 & 95 & 95 & 100 \\
24 hours & 100 & 100 & 100 & 100 & 100 & 100 \\
48 hours & 100 & 100 & 100 & 100 & 100 & 100 \\
\hline
\end{tabular}

Table 2. Percentage result of total dead larvae in 


\begin{tabular}{|c|c|c|c|c|c|c|}
\hline \multirow{3}{*}{$\begin{array}{l}\text { Repetition } \\
\text { concentratio } \\
\text { ns }\end{array}$} & \multicolumn{6}{|c|}{ Betel Leaf Extract } \\
\hline & \multicolumn{2}{|l|}{$7,5 \%$} & & \multicolumn{2}{|c|}{$10 \%$} & \multirow[b]{2}{*}{ III } \\
\hline & I & II & III & I & II & \\
\hline 30 minutes & 0 & 0 & 0 & 0 & 0 & 0 \\
\hline 1 hour & 0 & 5 & 5 & 10 & 10 & 10 \\
\hline 2 hours & 5 & 50 & 25 & 40 & 10 & 45 \\
\hline 4 hours & 45 & 60 & 80 & 65 & 35 & 95 \\
\hline 8 hours & 70 & 100 & 95 & 75 & 100 & 100 \\
\hline 12 hours & 80 & 100 & 100 & 90 & 100 & 100 \\
\hline 24 hours & 100 & 100 & 100 & 100 & 100 & 100 \\
\hline 48 hours & 100 & 100 & 100 & 100 & 100 & 100 \\
\hline
\end{tabular}

(Piper Betle L.) at concentrations of 2.5\%, $5.0 \%, 7.5 \%, 10 \%$ within 48 hours and also there were no deaths in Aedes Aegypti Sp larvae in containers containing negative controls in the form of Aquadest 96\%. Furthermore, in Figure 2, the graph results obtained on the death of Aedes Aegypti Sp larvae in 3 repetitions with a concentration of betel leaf extract (Piper Betle L.) $2.5 \%, 5.0 \%, 7.5 \%$ and $10 \%$ which had started effectively killed the Aedes Aegypti $S p$ larvae within 4 hours of observation. In tables
1 and 2, it is seen that the percentage of the total number of larvae which died at each concentration and 3 repetitions was the effectiveness of killing all larvae after the first 24 hours.

\section{DISCUSSION}

Based on the result of the research, it was obtained larvae toward the development of Aedes Aegypti $S p$ larvae is shown by the data analysis table, as follows:

Table 3. The percentage comparison of larvae death in each sample group in the first 4 hours.

\begin{tabular}{ccccccc}
\hline & Time & & 30 Minutes & 1 Hour & 2 Hours & 4 Hours \\
\hline Percentage & EDS & $2,5 \%$ & $0(0)$ & $0(10)$ & $15(25)$ & $65(75)$ \\
Of Dead & & $5,0 \%$ & $0(0)$ & $0(5)$ & $20(30)$ & $55(50)$ \\
Larva & $7,5 \%$ & $0(0)$ & $5(5)$ & $25(45)$ & $60(35)$ \\
[Median & $10 \%$ & $0(0)$ & $10(10)$ & $40(35)$ & $65(60)$ \\
(Range)] & & & & & \\
& P Value & & 1 & 0.0082 & 0.109 & 0.137 \\
\hline
\end{tabular}

Table 4. The percentage comparison of larvae death in each sample group in the first 8 to 48 hours.

\begin{tabular}{ccccccc}
\hline & Time & & 8 Hours & 12 Hours & 24 Hours & 48 Hours \\
\hline Percentage & EDS & $2,5 \%$ & $85(50)$ & $95(30)$ & $100(0)$ & $100(0)$ \\
Of Dead & & $5,0 \%$ & $90(30)$ & $95(5)$ & $100(0)$ & $100(0)$ \\
Larva & $7,5 \%$ & $95(30)$ & $100(20)$ & $100(0)$ & $100(0)$ \\
[Median & $10 \%$ & $100(25)$ & $100(10)$ & $100(0)$ & $100(0)$ \\
(Range)] & & & & & \\
& P Value & & 0.105 & 0.101 & 0.007 & 0.007 \\
\hline
\end{tabular}

Table 5. The difference statistically in minimal time/duration needed in each sample concentration

\begin{tabular}{ccc}
$\begin{array}{c}\text { The Concentration of } \\
\text { Betel Leaf Extract }\end{array}$ & $\begin{array}{c}\text { The minimum } \\
\text { period of killing } \\
\text { larvae (hour } \\
\text { [Median (Range) }\end{array}$ & P value \\
\hline $2.5 \%$ & $2(3)$ & \\
$5.0 \%$ & $2(1)$ & 0.044 \\
$7.5 \%$ & $1(1)$ & \\
$10.0 \%$ & $1(0)$ & \\
\hline
\end{tabular}


Table 6. LD50 from betel leaf extract in killing Aedes aegypti mosquito larvae after 1 hour of observation

\begin{tabular}{lllll}
\hline \multicolumn{1}{c}{ Model } & & & 1 \\
& Unstandardized & B & 24,333 & 8,000 \\
\multirow{5}{*}{ coefficients } & Coefficients & Std. Error & 11,498 & 1,878 \\
& Standardized & Beta & &, 763 \\
& Coefficient & & &, 054 \\
& T & & 2,116 &, 001
\end{tabular}

In table 3 and table 4 , the difference in the percent of dead larvae from each concentration was clearly seen in the observation after 24 hours of extracting the Aedes aegypti mosquito larvae. This can be seen from the comparison of the $\mathrm{p}$ value which had a value smaller than 0.05 . It was the observation after 24 hours. In table $\mathbf{5}$, the data from the above table showed a significant difference in statistics at the minimum time required for each sample concentration in killing Aedes Aegypti $S p$ mosquito larvae. This can be seen from the results of the kruskal-wallis analysis which showed $\mathrm{P}$ values were smaller than 0.05 . With the minimum period of concentration the fastest to kill the larvae seen at a concentration of $\geq$ $7.5 \%$, it was within 1 hour after giving extra betel leaf. In Table 6, the LD50 value of betel leaf extract was determined to stop the development of Aedes Aegypti Sp larvae after 1 hour of observation. To determine the LD50 value, linear regression analysis was first performed, and the table data above can be seen in mathematical equations to determine the LD50 value is as follows:

$$
Y=0.8 x-0.333
$$

Percentage dedifference in ad larvae (\%) was $\mathrm{Y}$ and the concentration of betel leaf extract (\%) was $\mathrm{x}$. While the $\mathrm{R} 2$ value of the equation was 0.396 , which means that the equation can predict the value of dead larvae of $39.6 \%$. From this equation, the $\mathrm{Y}$ value is substituted with a value of 50 to determine the LD50 value and the LD50 value was $62.92 \%$. It means that at 1 hour after administration of betel leaf extract a concentration of $62.92 \%$ is needed to kill half of the total larvae.
Besides, this research obtained results showing that there was a significant effect on the percent of died larvae total of 24 hours after administration of the extract. This was reflected in the $\mathrm{P}$ value which was less than 0.05 . The results of this research differed from Handayani's research because in that research, there were differences in the concentration of betel leaf extract (Piper Betle L) and the time of observation on larvae mortality in that study was only observation for 24 hours. After observing 24 hours of larval mortality in the research, the average total mortality was only $53.35 \%$ at the highest concentration of 1500 ppm while in my research, observations were of up to 48 hours (Handayani, Ishak, \& Anwar, 2013). Furthermore, the comparison when viewed for 24 hours of my research with comparative research, betel leaf extract highest concentration was $10 \%$ of larval mortality in the form of $100 \%$. which means that my research has been more effective because in the first 24 hours the death of larvae was $100 \%$, the number of larvae samples in the container together amounted to 20 larvae. However, in comparative researches, it was also statistically significant if the data at $\mathrm{P}<0.05$ were also effective in killing Aedes Aegypti Sp larvae.

\section{CONCLUSION}

There is an effect of larvicide from Betel leaf extract (Piper Betle L) toward the cessation of larval development of Aedes Aegypti Sp ( $\mathrm{P}=$ 0.007). for The effectiveness of betel leaf extract (Piper Betle L), there is a cessation of development at a concentration of $2.5 \%, 5.0 \%$, $7.5 \%$ and $10 \%$ which discontinuation the development of the entire larval population at 24-hour observation. This research found effective results in discontinuing the growth at $10 \%$ concentration with $100 \%$ larval mortality and LD50 value for Aedes Aegypti Sp larvae which effectively discontinued the 
development of larvae within 1 hour after administration of betel leaf extract with a concentration of $62.92 \%$.

\section{ACKNOWLEDGMENT}

The writer gives the gratitude to Head of the Universitas Prima Indonesia Foundation, Dr. dr. I Nyoman Ehrich Lister, M.Kes., AIFM., Rector of the University of Prima Indonesia, Dr.Chrismis Novalinda Ginting, M.Kes., And Dean of the Faculty of Medicine, University of Prima Indonesia, dr. Linda Chiuman, MKM., AIFO-K who has facilitated infrastructure so that this research can be completed well. The writer also wishes to thank the supervisor lecturer Dr. Hj. Riyani Susan BT Hasan MKT and also parents and friends who have supported the writer so that they can complete scientific writing.

\section{REFERENCE}

Adibah, A., \& Dharmana, E. (2017). Uji Efektivitas Larvisida Rebusan Daun Sirih (Piper Betle L.) Terhadap Larva Aedes Aegypti : Studi Pada Nilai Lc50, Lt50, Serta Kecepatan Kematian Larva. Jurnal Kedokteran Diponegoro, 6(2), 244-252.

Astriani, Y., \& Widawati, M. (2017). Potensi Tanaman Di Indonesia Sebagai Larvasida Alami Untuk Aedes aegypti. Spirakel, $8(2)$, $37-46$. https://doi.org/10.22435/spirakel.v8i2.61 66.37-46

Betriyon, \& Yahya. (2013). betriyon et al 2013.pdf. Fokus Utama, 20-28.

Handayani, Ishak, H., \& Anwar. (2013). Efektivitas Ekstrak Daun Sirih ( Piper batle L .) sebagai Bioinsektisida terhadap Kematian Nyamuk Aedes aegypti. Repasetory Unhas, 1-9.

Medicinal, I. (2015). Pasokan dan Permintaan Tanaman Obat Indonesia Serta Arah Penelitian dan Pengembangannya. Perspektif, 8(1), 52-64. https://doi.org/10.21082/p.v8n1.2009.

Nyamuk, L., Wahdaningsih, S., Armyanti, I., Belakang, L., \& Berdarah, D. (2016). Efektivitas Larvasida Infusa Daun Sirih ( Piper betle, Linn .) Abstrak LATAR BELAKANG Upaya untuk meningkatkan Angka Bebas Jentik yang masih di bawah target yaitu dengan Kuba dan Dari penelitian Damar dan Widiarti tahun 2005 , dilaporkan adanya resistens, 2(November), 636-645.
Physiaological, T. (2014). Studi fisiologis daun sirih 'temurose.' Jurnal Sains Dasar, 2(1), $7-12$. https://doi.org/10.21831/jsd.v2i1.2372

Purnama, N. (2017). DAUN SIRIH ( Piper batle L . ). Prosiding Seminar Nasional Mipa Iii, 437-441.

Sarjani, T. M., Pandia, E. S., \& Wulandari, D. (2017). FAMILI Piperaceae DI KOTA LANGSA. IPA Dan Pembelajaran IPA, I(2), 182-191.

Soedarmo, S. (2008). Infeksi virus dengue. Buku Ajar Infeksi Dan Pediatri.

Zuhud, E. A. M., Tumbuhan, L. K., Kehutanan, F., \& Pertanian Bogor, I. (n.d.). POTENSI HUTAN TROPIKA INDONESIA SEBAGAI PENYANGGA BAHAN OBAT ALAM UNTUK KESEHATAN BANGSA Alamat koresponden. 